This item was submitted to Loughborough's Research Repository by the author.

Items in Figshare are protected by copyright, with all rights reserved, unless otherwise indicated.

\title{
Biological sciences, social sciences and the languages of stress
}

PLEASE CITE THE PUBLISHED VERSION

https://doi.org/10.1080/01596306.2018.1394420

\section{PUBLISHER}

(c) Taylor \& Francis

\section{VERSION}

AM (Accepted Manuscript)

\section{PUBLISHER STATEMENT}

This work is made available according to the conditions of the Creative Commons Attribution-NonCommercialNoDerivatives 4.0 International (CC BY-NC-ND 4.0) licence. Full details of this licence are available at: https://creativecommons.org/licenses/by-nc-nd/4.0/

\section{LICENCE}

CC BY-NC-ND 4.0

\section{REPOSITORY RECORD}

Youdell, Deborah, Valerie Harwood, and Martin Lindley. 2019. "Biological Sciences, Social Sciences and the Languages of Stress". figshare. https://hdl.handle.net/2134/27697. 


\title{
Biological sciences, social sciences and the languages of stress
}

\author{
Deborah Youdell ${ }^{*}$ \\ School of Education, College of Social Sciences, University of \\ Birmingham
}

\author{
Valerie Harwood \\ Sydney School of Education and Social Work, Faculty of \\ Arts and Social Sciences, The University of Sydney
}

\author{
Martin R. Lindley \\ School of Sport, Exercise and Health Sciences, \\ Loughborough University
}

\begin{abstract}
There are well documented concerns with the imposition of high stakes testing into the fabric of school education, and there is now an increasing focus on how such tests impact children's 'wellbeing'. This can be witnessed in reports in the popular news media, where discussion of these impacts frequently refer to 'stress' and 'anxiety'. Yet despite a wealth of critical sociological literature, there is no work that is able to tell us about what is happening in the bodies of the teachers and children who are living this schooling in the day-to-day; whether this is best considered through the languages of 'stress'; or what the implications - emotional, educational, embodied of these experiences might be. This paper advocates and develops a trans-disciplinary approach that brings social and biological accounts together (Youdell, 2017) in order to address the 'more-than-social' of the emotionality of childhood and schooling (Kraftl, 2013). The paper details drivers and underpinnings for trans-disciplinary research into 'stress' in education; considers what such research might look like in practice; and interrogates what such understandings of 'stressful education' might be able to do differently for education. We seek out opportunities for trans-disciplinary connectivity and for new ways of seeing and knowing about learning. We consider what these ways of seeing and knowing might offer to education, both as tactical knowledges deployed as policy influences and as institutional and pedagogic practices.
\end{abstract}

Keywords: stress, assessment, sociology of education, bioscience, biosocial

* Corresponding author's email: d.youdell@bham.ac.uk 


\section{Introduction}

In early July 2017, the UK's Times Education Supplement ran a story entitled '[t]he primary assessment system is an endless anxiety merry-go-round, driven by an engine of mistrust' (Collingwood, 2017), in which the effects of high stakes testing were described as 'toxic'. The piece is illustrative of the many posts and articles that can be found on social and news media during testing season concerning the limited relevance and usefulness of the tests (The Guardian, 9 May 2017) and the harm done by them to students and sometimes to teachers (The Guardian, 1 May 2017).

Educationalists' concerns over the forms of high stakes testing that are now well established internationally have focused on the way that such tests alter the way that schools and classrooms operate, drive selective practices, and make inequalities worse instead of better (Apple, 2006; Gillborn, 2008; Gillborn \& Youdell, 2000; Thompson, 2016). More recently, however, popular and educational concern has shifted to the impact of these tests on children's wellbeing. In England, the national tests that are compulsory in primary schools have come to be discussed in popular and news media in terms of the 'stress' and 'anxiety' they cause children, reported as manifest in a range of ways: from tears and sleeplessness to one teacher's account of a child's eyelashes falling out (The Guardian, 1 July 2017).

There is a body of critical work in education that engages with the emotional dimensions of education, and foregrounds the importance of the psychic encounter between the teacher, the learner and learning (Bibby, 2011, 2017; Zembylas, 2007), as well as the social nature of feelings as they circulate in classrooms and between students and teachers (Harwood, Hickey-Moody, McMahon, O’Shea, 2017; HickeyMoody, 2009; Kraftl, 2013; Youdell, 2011). Recent studies by one of us offer compelling accounts, as we shall detail later, from students and parents of their 'stressful' experiences of contemporary schooling in general and assessment regimes in particular, giving weight to the popular accounts discussed above. Yet while work of this sort tells us much about the psycho-social dimensions of teachers' and students' encounters with assessment-driven education, it is not able to tell us about what is happening in the bodies of the teachers and children who are living this schooling in the day-to-day; whether this is best considered through the languages of 'stress'; or what the implications - emotional, educational, embodied - of these experiences might be.

In order to respond to this limit, this paper advocates and develops a transdisciplinary approach that brings social and biological accounts together (Youdell, 2017) in order to address the 'more-than-social' of the emotionality of childhood and schooling (Kraftl, 2013). The paper details drivers and underpinnings for trans-disciplinary research into 'stress' in education; considers what such research might look like in practice; and interrogates what such trans-domain understandings of 'stressful education' might be able to do differently for education. As we explore the range of bio- and social-science findings that suggest powerfully how 'stress' becomes instantiated in the body, and how learning gets blocked because of difficult or 'stressful' experiences, we seek out opportunities for trans-disciplinary connectivity and for new ways of seeing and knowing about learning. We consider what these ways of seeing and knowing might offer to education, both as tactical knowledges deployed as policy influences and as institutional and pedagogic practices. We conclude by arguing for a strategic openness to bio-knowledges in education studies. 


\section{What is 'stress'?}

Social media and press reports use 'stress' and 'anxiety' as interchangeable popular terms, calling up our common sense notions or experiences of feeling anxious or stressed. 'Stress' and 'anxiety' are referenced as though we know in advance what these are, how to recognize them, and what their implications are for children. Yet in scholarly psychological and biological research, as well as in clinical practice, the terms stress and anxiety have specific meanings that are embedded in the typological, diagnostic, and biological parameters of the disciplines. This means that when education commentators claim that children are made stressed or anxious by assessment regimes, this may not be demonstrable in the terms of the disciplines in which stress and anxiety exist as identifiable and diagnosable psychological and/or physiological conditions. Furthermore, when critical sociologically and psychoanalytically orientated work seeks to speak to feelings, their flows and their experiences - in particular difficult feelings or feelings of 'dis-ease' in the classroom (Bibby, 2011, 2017, p. 2) - this is seldom in terms of 'stress' or 'anxiety' (whether in scientific or lay terms) and so does not map straight-forwardly onto life science definitions. Key here is that existing sociologically informed education research provides important insight into the significance of feeling in education, its capacity to speak to the 'more-than-social' is limited (Kraftl, 2013) - it cannot tell us about the physiology, neuroscience or biochemistry of 'stress'.

This is not to suggest that psychological, neuroscientific, diagnostic or biochemical accounts of stress 'correct' sociological and common-sense understandings. What is meant by 'stress' shifts across biological processes, psychological state, unspecified popular usage and everyday experience. Indeed, this slipperiness in combination with embeddedness in biosciences may go some way to explain critical scholars' reluctance to engage the notion of stress. It is not our aim to synthesise these accounts of stress but to approach 'stress' as produced across domains - highlighting the entangled nature of these various accounts, including as they inform and are instantiated in experiences of 'stress'. As such we work across divergent ways of encountering and understanding what is described as 'stress', engaging with current understandings of the mechanisms and effects of stress drawn from the new biological sciences and interlacing this bioscience with nuanced social understandings of school processes, practices and relationships. As we pursue this trans-disciplinary engagement with stress, we anticipate that the concept of 'stress' itself might undergo a sort of 'metamorphosis' (Malabou, 2009).

With this approach, the paper does not seek to describe 'stress' as a problem with the child, young person, teacher or parent, an approach that would simultaneously situate the 'stressed' person as a problem. Rather, we want to reorient the discussion to foreground how schools themselves can be problems. There are moments in the brief history of compulsory Western schooling when schools were common-sensically considered to be a problem (Harwood \& McMahon, in press). For instance, in 1887 Dukes wrote persuasively about 'Delicate Boys', arguing that school is the problem (and not the delicate boy):

There are a certain number of boys in all schools who, though not ill, are not strong enough, for the time being, to bear the usual strain and exposure of school life, but need more home comforts and attention than can be well provided where the number of boys is large. (Dukes, 1887, p. 255. Original emphasis) 
This 'strain and exposure of school life' it would seem, has been disremembered. Taking a sociologically orientated critical stance we can see how such institutionally provoked strain is erased when discussions are centred on problems of the individual. This is also the case for teachers, where regimes of individualization and 'teacher blaming' shift ever more pressure onto teachers and render nigh impossible acts of resistance or counter tactics that seek to engage differently with students (Teague, 2014).

\section{Conceptual underpinnings}

In this paper we borrow from the scientific idea of the 'thought experiment' (Brown, 1991) to suspend a reading of the bio-politics of new biological sciences in education (Gulson \& Webb, 2016). Our aim is to explore what happens when we consider the possibility that new bioscience findings might have productive potential for sociological thinking about learning (Youdell, 2017; Youdell \& Lindley, forthcoming). In order to enable this consideration, the paper holds a distinction between bio-knowledges - the findings being generated in new biological sciences and bio-rationalities - the political and pedagogic discourses in which elements of these findings are deployed. While these are not neatly divisible and the space is not easily held, working with this distinction provides space for analytic experimentation with the multiple ways in which bio-knowledges can be deployed and their multiple productive potentials. This temporary suspension is underpinned by our engagement with a Deleuzian notion of the multiple interacting forces that produce assemblages (Deleuze \& Guattari, 2008); the growing acceptance of biological and social entanglements in leading social, political and cultural theory (Frost, 2016; Meloni, 2016; Roberts, 2015; Wilson, 2015); and the movement within education scholarship towards understanding emotion (Kenway \& Youdell, 2011; Youdell, 2011) and affective pedagogy (Hickey-Moody, 2014).

Leading-edge new materialist-informed critical education research concerned with feeling has detailed the distinctions between affectus, affection and affect and advocated for social science methods that can attend to these. Here, after Spinoza, affectus refers to changes in the body's capacities, while affection refers to the sensations of the body (Hickey Moody, 2014). Yet while there is important new sociological work in this vein (Hickey-Moody, 2013), research that can tell us about the biology of affectus and affection in relation to and resulting from difficult experiences of education is yet to emerge. In this paper, we begin to develop a transdisciplinary understanding of how difficult experiences impact affection and affectus - one that for the purposes of this paper we call 'stress'. Specifically, we consider how such 'stress' can be generated in the ebb and flow of pedagogic practices and relationships and the everyday of classroom and school life.

There remains a social justice imperative to question practices that isolate, segregate and disenfranchise - 'dividing practices' where 'the subject is either divided inside himself (sic) or divided from others' (Foucault, 1983, p. 208). Our own work has demonstrated how teachers' recognition and misrecognition of students sorts and hierarchises students in ways that make education success available to some and forecloses this for others (Harwood, 2006; Youdell, 2006). Furthermore, our work has argued that particular scientific knowledges are deployed as psychopathological discourses that work as key contributors to these dividing practices in institutional education (Harwood \& Allan, 2014). Nevertheless, we suggest here that the 
repudiation of scientific knowledge in how critical education scholarship, even if this is working to identify and critique practices that divide, could be divisive itself and reveal how this work might be caught up in its own 'standardized codes' (Arendt, 1981):

Clichés, stock phrases, adherence to conventional, standardized codes of expression and conduct have the socially recognized function of protecting us against reality. (p. 4)

The possibility that biological processes might be embroiled with social processes is, we suggest, important for critical education scholarship to contemplate. In his 2013 paper, Peter Kraftl explores the possibility of understanding the emotional geographies of children's lives through an encounter with the 'more-than-social' (p. 13). He suggests we deploy 'hybrid' conceptions of childhood that move beyond a biology/sociology dualism and instead considers their entanglements. Kraftl's assertion is that the fields of childhood studies and education do not understand childhood emotion well enough, and his aim is thus to 'stretch' our conceptions of 'the relationality of children with adults and, indeed, the relationality of children's emotions' (p. 14). Doing this in relation to stressful experiences of education, and the instantiation of stress in the bodies of children and teachers is, we argue, an important part of this endeavour.

\section{The research}

This paper brings together a range of data and analysis generated from a series of research projects in which the authors are involved. At the centre of the paper is a British Academy-funded project synthesising insights from sociology of education and new biological sciences to better understand the production of learners and learning. ${ }^{1}$ This project involved extensive literature research across epigenetics, metabolomics, and neuroscience as well as education and sociology and subsequent analysis, synthesis and development of a framework for trans-disciplinary biosocial working in education (Youdell, 2017; Youdell \& Lindley, forthcoming) underpinned by an understanding of assemblage and the folding together of the multi-factorial influences that produce complex phenomena such as learning (Barad, 2007; Deleuze \& Guattari, 2008; Roberts, 2015). Stress has been one of an array of trans-domain phenomena that have emerged as significant in this analysis.

We also draw on primary data from two Australian projects concerned with how people who have experienced educational disadvantages talk about education and educational futures. ${ }^{2}$ These data sets enable us to consider how institutional education and the educational futures of children are talked about and envisaged by parents who have experienced educational disadvantages and who live in communities experiencing socio-economic disadvantages, and consider young people's descriptions of difficult experiences in education and how these are influential in forming ideas about educational futures (Harwood et al., 2017). In the first, 'Getting an Early Start to Aspirations' (GAESTA) project we are working on adapting social marketing methodologies and testing how these can be refined and used in a collaborative way in communities were there are significant educational disadvantages. Research from this project reported in this paper draws on surveys $(n=487)$ and semi-structured interviews $(n=100)$ conducted in 2015-2016 with parents in eight sites in regional NSW, Australia. The second, 'Imagining University Education’ (IUE) project involved semi-structured interviews with 263 young people 
in youth service settings in five Australian states. (For further discussion and background on the research site psuedonyms, see Harwood et al., 2017). Data identification and analysis drew on close reading of the two data sets and NVIVO searches for words such as 'stress'. A close examination of the IUE data set node 'feelings about education' was performed to analyse how young people who have had difficulty with education describe their feelings about school environments.

Finally, we draw on biological data generated through projects involving one of us which used mass spectrometry to capture and analyse the volatile organic compounds in exhaled breath, including compounds that are metabolites of hormones associated with physiological expressions of/responses to stress (Heaney et al., 2016; Reynolds et al., forthcoming).

These data sets combine to enable us to look at stress and learning through multiple lenses and bring back into the frame of potential thinking, analysis and practice factors and forces that are left out when research remains within a single domain.

\section{Education 'stress'}

When we turn to think through 'stress' and education - the distress that high stakes tests sometimes provoke, difficult encounters between teachers and students, or the flows of impacts onto parenting young children - there is a notable absence of discussion on stress in the sociological literature (see as an exception Munt's 2004 discussion of teacher stress). The question of the relationship between 'stress' and education is generally left to areas such as developmental psychology (Cummings, Greene, \& Karraker, 2014; Shaffer \& Kipp, 2013) and more recently developmental epigenetics (Bakermans-Kranenburg \& van Ijzendoorn, 2013; Groeneveld et al., 2013; Noble et al., 2015; Plak et al., forthcoming; van Izjendoorn et al., 2011), or to non-academic writing such as blogs (Levy, 2017) and Facebook posts.

Nevertheless, there is considerable work in sociology of education critiquing the sites and practices of institutional education. Critical sociological work engages the difficult relationships to institutional education that occur in a range of sites and practices, for example in classrooms or playgrounds (Saltmarsh \& Youdell, 2004; Youdell, 2010). Likewise, as noted earlier, there is a strong line of critical work on the force of high stakes testing regimes (Apple, 2006): No Child Left Behind in the US (Booher-Jennings, 2005); General Certificate of Secondary Education (GCSE) assessment in the UK (Gillborn \& Youdell, 2000); the Programme for International Student Assessment (PISA) run by the OECD (Sellar \& Lingard, 2014); and National Assessment Program - Literacy and Numeracy (NAPLAN) in Australia (Thompson, 2016). While these bodies of work are precisely attuned to the productive force of institutions, pedagogic encounters, and tests and their attendant practices, to date this scholarship has not considered how biological processes are produced through and intra-act with these social forces.

In contrast, in the popular education literature new scientific ideas are having significant influence. New findings from neuroscience are reinvigorating attachmentbased approaches to early child care (Hughes \& Baylin, 2012) and related 'brainbased' teaching approaches (Bomber \& Hughes, 2013) which foreground attachmentbased pedagogic relationships; the reduction of learners' 'anxiety' and other 'affective filters' that inhibit learning (Willis, 2014); and the promotion of self-awareness, mindfulness and 'grit' (Perez, 2015). Perhaps more significantly, research in new 
biological sciences is having an increasing influence on education policy. In early years policy in particular, there has been a mobilization of data from functional magnetic resonance imaging (fMRI) and developmental epigenetics (Allen, 2011). This has been drawn on to argue for interventions into parenting and early years education, especially those targeting the poorest families. While the expressed intentions brain-based education and interventions into early years care have been to enhance learning and extend services and support to poor families, there has been sustained criticism of the way these mis-use the available scientific evidence and are embedded with a deficit account of poor families (Baker, 2015; Wastell \& White, 2012). The policy use of neuroscience and epigenetic findings has been subject to particular criticism, with the argument made that the deployment of these forms of data as policy evidence extends the reach of governance into the interiority of the body at the same time as it cements the nature of these bodies and subjects (Baker, 2015; Edwards, Gillies, \& Horsley, 2015). While these critiques are compelling, we argue they should not foreclose thinking across the domains of sociology and biology.

\section{'Stressful' places and practices}

While 'stress' has not been a focus of sociological work in education, our work in sociology of education has brought to attention the blockages and problems that children and young people encounter in institutional education (Harwood, 2006; Youdell, 2011) and how these are situated as 'deficits' within the student as a sweeping diagnostic apparatus is applied (Harwood, 2010; Harwood \& Allan, 2014, Youdell, 2006, 2011) without recognition of how school and teacher practices are implicated in these forms of subjectivation (Youdell, 2006). As part of this body of work, feeling is being recognised as an important component of school processes and effects. Recent sociological work has sought to identify how affect, and particularly the sociality of affect that flows between bodies and across school sites, produces particular teacher, learner and abject bodies (Harwood, 2017; Kenway \& Youdell, 2011; Youdell, 2010; Youdell \& Armstrong, 2011). The importance of feeling has also been examined from a psychoanalytic perspective in terms of how learning becomes blocked in difficult educational encounters (Bibby, 2011, 2017). Drawing on research based in a London primary school and in a climate of testing, Bibby's (2011) work describes both children's and teachers' difficult experiences of education, such as the dis-ease provoked even by 'being in the top or middle group since the prospect of 'moving down' loomed generating a climate of fear' (Bibby, 2011, p. 51). Drawing on Winnicott (1971), Bibby asks '[w] hat kind of mirror do assessments hold up? In what ways were the teachers able to 'be there' to feed, and enable, playful and creative responses to ideas?' (p. 46).

The interviews from the IUE project conducted by one of us support the case that schooling entails difficult experiences that might be understood as 'stressful' (Harwood et al., 2017) and data from the GAESTA project, shows how practices such as high states testing provoke responses from parents of young children that might be understood through a lens of 'stress'. The account of a young man who left school at age 16 is illustrative of the way that young people talk about these experiences of school:

You know, you're there to learn but at the same time you can't learn when you're under a lot of pressure I guess. That pressure was just hitting everyone and yes, just things started 
happening but yes, I didn’t go to Year 12; I stopped at Year 10 - after Year 10 - and then got

a job at council and now I'm here now. (Flindersvale ${ }^{3}$ Interview, IUE, 2013)

This account of 'pressure' suggests a desire to learn curtailed not by the student but by a difficult environment; connections between the negative impact of school and learning that were emphasized throughout the interviews. It is important to pay heed to such accounts that clearly describe how such relationships with schools and teachers impact on young people, with significant life impacts on educational futures, such as shutting down the idea of university education (Harwood et al., 2017).

As we have discussed, testing is one of the iconic practices of contemporary education that brings the experience of an activity that is popularly understood as 'stressful' into the clearly marked out space of institutional education. When we analysed the GAESTA data for mentions of the word 'stress', the NAPLAN test (National Assessment Program Literacy and Numeracy test) emerged as the key practice that caused concern. NAPLAN is administered by the Australian Curriculum and Assessment Reporting Authority (ACARA) and, like its counterparts elsewhere, is an annual literacy and numeracy assessment for students in particular age grades (in Australia years 3, 5, 7, and 9). NAPLAN testing, like high stakes testing elsewhere, has been subject to critique. Lingard, Sellar and Savage (2014) argue these testing practices impact notions of equity and social justice, which 'are being transformed through the national and global reworking of education into a field of measurement and comparison' (p. 711). Such 'measurement and comparison' was keenly felt by the parents in the GAESTA study, and was wholly disconnected from a sense of social justice or equity. The following discussion with a small group of parents of young children in a regional NSW town exemplifies parents' accounts of the 'stress' and 'pressure' experienced in relation to NAPLAN:

Parent 1 But I think a lot of emphasis with the government stuff really focuses on education but with the testing it's just so over the top. You just see the NAPLAN test and it just creates so much stress among the children ...

Parent 2 ... Like I actually sat the NAPLAN test last week and oh my goodness. Fortyfive minutes for these little kids to complete this workbook. It was just mindboggling. I'm an adult and I sat there and I was like looking at the clock and going 'Oh my God I'm not going to finish. How embarrassing'. And they're only little kids. They're tiny. And the pressures are just - it's just not -

Parent 1 Too much.

Parent 3 Yeah. I think that needs to be a bit of a focus moving forward. Just that pressure.

Parent 1 So these are the things that are coming across. That's the pressure that the schools are under, the teachers are under, the families are under and the students, like they're just really freaking out.

(Parents of young children Group Interview, GAESTA, 2016)

These parents included some with very young children and some with children who attended school, and so had experienced NAPLAN. While it is clear to them that NAPLAN is imposed externally onto children and teachers alike, they also state that it both inappropriate and bad for children - it is 'over the top', 'mindboggling', 'too much'. When one of the parents was asked 'what sorts of things about education are you talking about when you're around your kids?', the response wasn't reading or writing or maths or science. The response was 'Our focus kinda this year is actually making sure our kids are mentally okay and emotionally okay' (Longitudinal interview, GAESTA, 2016, emphasis added).

These experiences of the pressures of testing influence how education is 
discussed - or rather, not discussed - with younger children, provoking an orientation that protects children from NAPLAN. Several parents reporting responding to children's concerns by downplaying the importance of NAPLAN and reassuring children over possible results. For instance, one parent reported how she talked about NAPLAN with her young child: 'Please don't stress about this, if you don't do well, it's okay'. And another explained that with her primary school aged child education talk involves stating: 'There's no point making yourself sick over a test when ... if you are honestly trying your very best, I'll be proud no matter what' (Longitudinal interview, GAESTA, 2016).

In this research cohort, then, when talk is occurring with children about education, it is talk focused on ensuring children 'are mentally and emotionally okay' in response to schooling and the landmark moment of the NAPLAN test.

The findings of the IUE and GAESTA studies give credence to media accounts of the 'stress' provoked by high stakes tests and the institutional practices that accompany these. Yet as in the popular literature, these accounts use a commonsense notion of 'stress' or 'pressure' and significantly, are not able to access the affectus - the changes in bodily capacity - that are enfolded into these experiences. The sociologically-based literature on the effects of school processes and practices and the importance of feeling in schooling can tell us much about the processes and practices that produce difficult experiences and flows of affects that we might name as 'stress', but it is much less able to tell us about the affection and affectus of 'stress' itself.

To think further about these embodied experiences and bodies' changed capacities, and to open up new space for thinking about 'stress and schooling', we turn to literatures in the new biological sciences where, unlike in sociology, stress is widely studied and considered to be well understood. Here we take up these biological understandings of stress. The brain chemistry of stress in humans is set out as follows:

\footnotetext{
In humans, one of the key physiologic markers of stress is activation of the hypothalamicpituitary-adrenal (HPA) [or stress] axis, with the accompanying secretion of corticotropinreleasing hormone from the hypothalamus, adrenocorticotropic hormone (ACTH) from the pituitary and cortisol from the adrenal cortex. (Dedovic et al., 2005, p. 320)
}

In this account, stress is identifiable through and as a series of neurochemicals and the cellular activation these provoke. The immediate and lasting effects of these neurochemicals are a key focus of stress research:

[I]n the stress literature [we find reported] the effects of early social stress on gene regulation and the epigenome, which then leads to long-lasting changes in behavior, cognition, mood and neuroendocrine responses predisposing to or sheltering from stress related diseases later in life. (Cacioppo et al., 2013, p. 2)

Many of these findings are from experimental animal work that has suggested sustained but potentially reversible effects of stress in rodents. For instance, rats exposed to electric shock (experimentally coded as trauma) in novel environments show on autopsy that this induces patterns of DNA methylation and histone acetylation in specific brain regions that are associated with memory (a common neuroscience proxy for learning) (Molfese, 2011). Yet work that introduces rats to novel objects shows that also inducing 'stress' in these novel object encounters impedes memory (Bevins \& Besheer, 2006; Leger et al., 2013). If we are willing to extrapolate to human children from these animal studies then this distinction between 
'trauma' and 'stress' may be important for education as it gives us pause to consider how stress-inducing educational practice may well have lasting (but not irreversible) neurological effects that block learning. ${ }^{4}$

This initial consideration makes evident that taking seriously an encounter between sociological work concerned with difficult experiences of schooling and biological work concerned with biochemical mechanisms through which experiences of stress have broader and/or longer-term implications means articulating research undertaken for distinct and often divergent purposes. The social neuroscience and social genomics research above concurs with the accounts of parents who took part in the GAESTA study and the young people in the IUE study, as well as with sociological accounts of children's classroom dis-ease, but in registers so different that finding a point of potential articulation can be difficult. The sociologists can observe blocked learning, parents can see and feel that 'stress' is harmful for their children, the biological scientists can suggest molecular mechanisms whereby this harm is instantiated and retained in the body. 'Education stress', this suggests, is simultaneously social, relational, psychological and biological and needs to be understood across these lenses.

One area of epigenetic work relating to neurochemically-defined stress that has raised criticism from sociologists (Gillies, 2008; Kenney \& Müller, 2016) is animal model work that examines the effects of limited early care in rats and shows epigenetic changes in endocrine function and brain structure/activation which have downstream negative impact on the rat's capacity to down-regulate stress-induced hormones and on learning and sociality (Champagne, 2009; Gudsnuk \& Champagne, 2012; Weaver et al., 2014). The parents whose accounts are reported above talk about stress in lay terms as they report it invoked in their children by school processes and practices and the sociological literature sets out the restrictive subjectivating force of school practices and teacher-student relationships (Bibby, 2011; Youdell, 2011). In contrast, much epigenetic work suggests the home, and more precisely the motherchild relationship, as the key driver of these epigenetic changes. Nevertheless, as Kraftl's (2013) highlighting of the 'more-than-social care relations' between children and educators begins to suggest, the possibility that non-nurturing relationships beyond the mother-child dyad have effects at a cellular level, and that these might impact capacities for biochemical regulation, learning and sociality demands consideration in the context of relationships inside classrooms.

In human studies in neuroscience, perceived and assessed social isolation are the dominant proxy for stress, and impacts are repeated in association with other adverse social experiences including bereavement, post-traumatic stress (PTSD), and low socio-economic status/poverty. These experiences or factors, then, do not all map neatly onto the sorts of relational, pedagogic or systemic factors that sociologists might observe in schools, but they do offer some points of potential articulation. Such human studies rely on blood, cord blood, buccal (cheek) cells, or saliva, and are predominantly conducted with people who describe personal histories of abuse or depression, diagnoses of psychiatric disorders, or personal or maternal histories of domestic violence. Brain tissue from people who have died by suicide have also been analysed. Clearly the focus in such human studies has been on populations identified a priori as 'pathological', in tension with sociological commitments to the constitutive nature of such diagnoses and making translation of findings to 'regular' (Slee, 2011) school children problematic. There is some direct biological evidence of stress in children in school, specifically evidence of sustained and notable increases in 
the stress-related hormone cortisol, as measured by cortisol in hair samples, as children transition from nursery into school (Groeneveld et al., 2013).

It is argued in epigenetic neuroscience that sustained stress, understood neurochemically, results in a 'conserved transcriptional response to adversity' (CTRA) (Cole, 2014, p. 2) - the way in which cells transcribe DNA information and so function - which increases inflammatory responses and diminishes anti-viral responses and so has persistent detrimental health effects (Cole, 2014). Furthermore, experimental studies in humans suggest that exposure to 'stressors' such as those identified above, inhibits future biological capacities to cope with stress, with extreme or 'toxic' 'stress' said to impair stress responses through 'dysregulation of the HPA axis' (Romens, McDonald, \& Pollak, 2015, p. 304). Yet while these findings may seem compelling, it is important to recognise that they 'cannot directly address causality or the cellular processes occurring within the brains of living children' (p. 307) and so mechanisms remain unproven. Nevertheless, these studies in humans show that biochemical responses to 'stressors' may provoke changes to how cells function that become persistent and that impair a person's future cellular capacity to cope with 'stress' (as well as inflammatory and viral responses) and concurs with parents' concerns about the 'stress' that their children experience around testing and other school practices.

Imaging neuroscience uses functional magnetic resonance imaging (fMRI) to map patterns of activation of the human brain as it is exposed to 'stressors' inside the scanner. One approach to inducing 'stress' is to ask subjects to undertake tests, such as time-pressured arithmetic, often with an associated 'social evaluation threat', for example, that the results of the test will be made known to peers. The Montreal Imaging Stress Task (MiST) is one such test, and has been used to map brain activation patterns associated with 'stress' (Dedovic et al., 2005).

Insert Figure 1. fMRI imaging of brain activity during MiST test. Source: Dedovic et al 2005.

Studies have also brought inflammatory and neural responses to 'stressors' together, showing markers for inflammation in blood plasma and under fMRI activation of the amygdala - a brain region involved in responding to threat, including by the sympathetic nervous system (SNS) - and of the dorsomedial prefrontal cortex (DMPFC) - a brain region involved in 'mentalising' others' thoughts/feelings - in response to negative social evaluation (Muscatell et al., 2016). In this and other studies, brain activation varies across those who perceive themselves to have higher and lower social status, with those with lower self-ranking social status showing greater DMPFC (mentalizing) activity and greater inflammatory responses ('proinflammatory cytocine IL-6') (Muscatell et al., 2016, p. 918). Thinking about social status and evaluation in the classroom, this brain imaging work suggests that children who perceive themselves to have low social status (e.g. assessed by teachers as being of 'low ability' or 'badly behaved') are likely to be more focused on evaluators' negative feedback and the reasons for it (DMPFC activation) and be more affected by this negative evaluation than children who perceive themselves to have higher social status (e.g. those assessed and treated as 'bright', 'popular' and 'wellbehaved'). Again, the brain imaging work concurs with sociological work detailing the effects of the subjectivation of students and the sorting and selecting practices that this is embroiled with. Yet, like animal models and non-tissue specific epigenetic studies, extrapolating from composite brain images generated from multiple subjects 
during scanner tasks to complex social situations is problematic, as is moving from brain activity to function (Fischer, Goswami and Geake, 2011), and especially function in complex and mobile fields of multiple influences (Howard-Jones, 2014; Youdell, 2017) such as classrooms.

\title{
Mass spectrometry and breathing in learning spaces
}

\author{
Interviewer: Where do you go to get an education? \\ Participant If the teacher's nice to me then I'll do all their work and I'll get into it. \\ (Sumerton Interview, IUE, 2013)
}

In metabolomics, which considers the body's metabolic responses to stimuli, and in analytical chemistry, analysis of volatile organic compounds (VOCs) in exhaled breath is emerging as an important approach (Heaney et al., 2016; Reynolds et al., forthcoming; Turner et al., 2013). Such approaches have the potential to provide new orientations to and insights into affect in schooling through their capacity to identify biomarkers for 'stress' in the exhaled breath of the classroom. In order to think carefully about this potential, we detail analysis of VOCs in exhaled breath and what this has (and has not) been able to say.

Returning to the specific educational issue of the affect invoked by high stakes testing and our argument that, drawing on Spinoza (Hickey-Moody, 2013) far too often this impacts affection and affectus (stress), there already exists mass spectrometry analysis of the exhaled breath of young people in test environments (Turner et al., 2013). Turner et al. exposed participants to a 'stressor' in the form of a paced auditory serial addition test, along with the social threat of public results, much like in Dedovic's brain imaging work discussed above. Importantly, Turner's participants undertook the test (and controls) in a classroom environment providing pre- and post- exhaled breath samples which were analysed using gas chromatographic-mass spectrometry (GC-MS). This allows the VOCs in the exhaled breath sample to be mapped and matched against known compounds. It is important to understand that this technology and method is emergent and it is not known what all the compounds evident in a mass spectrum are. Turner and colleagues identified six components that were sensitive to the invoked stress. Four of these were shown to be indole, 2- hydroxy-1-phenylethanone, benzaldehyde and 2-ethylhexan- 1-ol, while the remaining two components were not identified with certainty.

Insert Figure 2. Volatile Organic Compounds in Exhaled Breath during PASAT Test.

Legend: Overlaid extracted ion chromatograms (XIC) responses for stressed experimental session (dashed line) and neutral experimental session (solid line) for stress sensitive breath components: indole $(\alpha 1)$, 2-hydroxy-1-phenylethanone $(\alpha 2)$, 2-methylpentadecane $(\alpha 3)$, unknown terpene $(\alpha 4)$, benzaldehyde $(\alpha 5)$ and 2-ethylhexan-1-ol $(\alpha 6)$ from a single male participant. The intensities (IR) displayed have been normalized with respect to the neutral experimental session to indicate those components that have been up-regulated and down-regulated as a result of undertaking the PASAT. (Source: Turner et al., 2013)

The most potentially significant of these compounds is indole, because this is 'associated with the production of the essential amino acid tryptophan, which in turn is part of the pathway that produces serotonin' (Turner et al., 2013, p. 7) which in this literature is itself associated with cardiovascular and psychological stress. This massspectrometry analysis of VOCs in exhaled breath offers traces of cellular stress 
responses to testing that are pertinent to schooling systems in which testing is embedded as a core practice, and might open a new lens onto the feelings and experiences of the students who are tested and the teachers who do the testing. Yet Turner and colleagues emphasize that having identified VOCs it is not straightforward to assign causes to or from them, and suggest the need for further verification - 'it is perhaps too soon to postulate biological origins and roles for these VOCs as part of a stress-sensitive response in breath’ (Turner et al., 2013, p. 7).

However, another recent study by Williams et al. (2016) in which 'biochemical stress' responses are foregrounded is less cautious. Williams et al. undertook atmospheric mass spectrometry analysis of VOCs in exhaled breath from a cinema auditorium. This was repeated over an extended period of time and while films of a range of genre were screening. By coding the content of each film and sampling to coded segments the team was able to predict what masses would be evident in particular samples. Like Turner and colleagues' work, Williams and colleagues do not necessarily know what each VOC is, but they can predict that it will consistently be present during a segment of film; these findings are suggestive of social flows of VOCs in response to particular events on screen. In specific relation to 'stress', across screening of Hunger Games 2, spikes of carbon dioxide, isoprene and acetone were evident at key 'stressful' points in the narrative of the film. Isoprene is of particular relevance as it is produced in breath holding and muscle twitching (responding to stressors) and linked to cortisol (a key stress hormone) via cholesterol; that is, it is taken in the study as a 'stress signature'.

Insert Figure 3. Atmospheric stress in the cinema

Insert Figure 4. VOC mass spectrums in cinema auditorium during types of film segment

Williams and colleagues' study, then, offers a starting point for atmospheric analysis inside school settings for education researchers concerned with the ways that schooling practices might produce 'biochemically stress-laden environments', and the ways that these VOCs might flow across spaces and bodies and in turn be folded back into the processes, practices and subjectivations of schooling. Despite Turner and colleagues' reticence, we want to pursue the possibility that GC-MS of VOCs can offer a window into the flows of feelings - affection - and bodily capacities - affectus - in classrooms that have been the focus of theorizing and ethnographic work in sociology of education, but which remain out of reach to sociological methods. William's methodology, which attends to atmosphere, not individual persons, moves attention to the social flows of feeling in school settings, analysis of VOCs in the classroom could identify those moments when institutional practice provokes peaks in stress-related VOCs, or it might offer the unsettling evidence that in some classrooms stress is chronic.

Together, these VOC studies demonstrate that a single body and collected bodies do different things - produce different volatile organic compounds - in response to different stimuli, that this is patterned and meaningful, and that we may be able to map between particular practices, VOCs, affections, affectus, and selfexpressed feelings. Atmospheric and individual analysis of VOCs in exhaled breath could speak to collective and individual 'stress' responses within particular sorts of pedagogic situations, assessment modes and conditions, and teacher-student encounters. That is, VOCs in exhaled breath could offer us new insight into what sorts of education are good for children, and what sorts of education might actually work 
against its own ends and the social and health wellbeing of students themselves. Mass spectrums in students' exhaled breath or in classroom atmospheres would not suggest an individual normative versus pathological response; rather in interaction with sociological evidence they have the potential to show mutability and flows, and the folding together (Roberts, 2013) of bodies, subjects, settings, artefacts, interactions, systems, structures, experiences, pedagogies and relationships.

\section{Conclusion: biosocial thinking and doing education differently}

Peter Kraftl (2013) has asked:

[W]hat is it that we seek to gain from knowing, and intervening in, how children feel? in what ways can our fine-grained analyses of the multiple workings of emotion in children's lives 'speak back' to both prevailing orthodoxies and counter-narratives about the deployment of emotion in mainstream or alternative schools, youth work settings, health settings, et cetera? (p. 21)

We are not simply advocating attention to emotion in education (see e.g. Kenway \& Youdell, 2011; Youdell \& Armstrong, 2011), we are suggesting attention to the simultaneously biological and sociological aspects of feeling - affection and affectus - in classrooms. This folding together of the social and the biological is increasingly called up as 'biosocial', and some of us have worked with this notion and advocated for biosocial education elsewhere (Youdell, 2017, Youdell \& Lindley, forthcoming). However, the biosocial is not unproblematic. Biosocial approaches currently take a number of forms, with their underpinnings ranging from the biological to empirical social sciences and the critical humanities. This means that in some manifestations the biosocial is largely uncritical and can appear as the annexation of weak accounts of the 'social' by 'social biology' (Meloni, 2014), while in others it encompasses radical mixing of nature and culture (Frost, 2016; Meloni, 2016). Despite the contestation and risks of the concept, and critical sociology's abiding reluctance to engage the biological, we argue the biosocial can help us to think about and engage in 'a renegotiation of the boundary between biology and sociology and the making of a new sociological imagination’ (Meloni, Williams, \& Martin, 2016, p. 12).

Here we suggest that a biosocial understanding of 'school stress' has the capacity to provide important new insight into which systems, settings, pedagogies, teachers and children are most affected by 'education stress'; in what ways; and through the convergence and intra-action of what biological and social processes. In doing so, this biosocial approach promises to bring nuance to the 'stressful education' debate, showing what it means to say that children are 'stressed', how children are 'stressed', how this 'stress' is distributed, why it is distributed in these ways, what the immediate and longer-term implications of this 'stress' may be; and so why this 'stress' is a problem. In turn, this enables us to present an invigorated case for different systemic, pedagogic and relational approaches in education.

We propose that biosocial research into stress in education might take the form of biosocial assemblage ethnography (Youdell, 2014; 2017), retaining its concern with the intra-action and convergent forces of systems, structures, expert knowledges, how policy is enacted, how these play out in everyday life, the minutiae of practices, subjectivities, and feelings but also including biological processes in this. Such an approach demands method integration, using a range of technologies in the classroom (such as Mass Spectrometry, EEG, and video recording), and giving up, once again, 
on longstanding ethnographic desires for a 'natural' or undisturbed site. In turn, data is comprised of policy, demographics and attainment data, artefacts, observations and accounts as well as patterns of brain connectivity and volatile organic compounds. In analysis, biological methods are not used to check or test sociological methods. Rather, analysis explores what biological and sociological forms of data can say together - what becomes possible when expressive as well as representation data (Hickey-Moody, 2014; Kraftl, 2013) are set alongside EEG and VOC data, taking seriously their connections and disconnections. This means accepting our 'degrounding' from our usual disciplinary locations (Butler, in Atkinson and De Palma, 2009), 'rough and tumble' across disciplines (Wilson, 2015), and the transformation of our underpinning concepts (Malabou, 2009) and knowledge domains (Youdell, 2017). Stress may never be the same again.

Biosocial understanding of 'school stress' has the potential to change education at a system level, from policy and directives, accountability measures, curriculum and assessment strategies, to classroom organisation, pedagogies and relationships. Attending to the biosocial and its implications for children's wellbeing and learning demands we prioritise understanding when 'school stress' becomes harmful, the efforts to eradicate 'harmful stress', and the promotion of care relationships. Imagining that empirical biosocial study will confirm that high stakes tests and their attendant institutional and pedagogic practices provoke 'stress' in children that has lasting detrimental effects, we envisage a major driver for a shift in policy away from high stakes testing and towards alternative forms of assessment that do not evoke such stress - either as subjectively described by children, observed by parents and teachers, apparently manifest somatically, e.g., through sleeplessness, tearfulness, or potentially identified biochemically in exhaled breath or neurologically through brain-imaging. Such a shift is profoundly indicated by existing research discussed here and, we anticipate, will be evidenced through critical biosocial research in education settings in the near future. Evidencing the need to move away from high stakes and high stress testing has the potential to also shift pedagogic practices and relationships when these no longer have to be in the principal service of test results. Different forms of relationality, pedagogy and assessment can emerge. A biosocial approach to 'stress in education', then, is absolutely not a move away from analysis of structures and systems towards the remedying of 'individual stress' mindfulness on its own will not do, and in fact only reinforces an individualised framing that fails to recognise the systemic causes of 'education stress'. Our biosocial assemblage ethnography of 'school stress' is yet to be tested empirically, but we suggest that our interrogation of the extant and primary data offered here already suggests a shift away from children's stress management - mindfulness exercises and/or desensitization through repeated practice tests - towards 'stress removal' surely the stress-free school is the most conducive to effective learning and high attainment?

In the absence of significant policy change, we consider the 'spaces in between' where educators might do things differently in pursuit of the 'low-stress school' and the 'low-stress classroom'. Teachers might foreground relationality in their classrooms and prioritise this over high stakes test or the regimental production of docility and managed behaviour. Headteachers might do likewise, and give leave to staff for outcomes in high stakes tests to slip in exchange for this relationality and a low-stress classroom. It is not necessary to repeatedly or routinely measure VOCs in the classroom, teacher or child, or produce brain images of the child. Rather, we suggest that having established the effects of biosocially understood stress and the 
stressfulness of many contemporary western classrooms, educators and policy makers should proceed with this understanding and a corresponding commitment to the lowstress school.

By looking at 'stress' and learning through multiple lenses - including those offered by a range of biosciences - we bring back into the frame of potential thinking, analysis and practice the possibility that stress is not a disease of the mal-adapted individual but is something that flows through social spaces, is produced through interacting social and biological forces and can be apprehended across scales from the distribution of outcomes in high stakes tests to the flows of volatile organic compounds in breath. Our understanding of the enfolded production and products of stress becomes simultaneously concerned with social structures, institutional practices, representation and meaning, subjectivities, feeling, neural networks and molecular functions. It is not just the case that social processes and biological mechanisms flow together, rather they are enfolded together in the dynamic production of the phenomena of stress. By working across biosciences we think across modes of scientific enquiry and forms of evidence that are not ordinarily articulated together, and are reminded to also work across modes of sociological enquiry and forms of evidence. Doing this enables our thinking to traverse orders, scales and temporalities. Stress can be understood at once as instantiated in the body through early adverse experiences effecting enduring but reversible changes to cellular functions and neural network and endocrine responses; provoked through relational encounters with others, objects, ideas and practices in the present which produce effects in the body and impact what a body-person can do in the world; a social force and flow.

Better understanding stress and its negative impact on our capacity to learn has profound implications for education. To be able to make tangible the cellular effects of stress is to be able, echoing Bibby (2011), to 'hold a mirror' of a different sort to policy makers who insist on the domination of high stakes testing and the institutions who are required to impose these regimes on children. The understanding of stress and its effects that is offered by this biosocial reading of the enfolding of flows and forces insists that educational practices that provoke stress are precisely contrary to learning and so indefensible. Given the negative impacts of stress on learning as well as health, and the provocation of stress by negative evaluation and testing, it seems to us that this bio-knowledge can be most useful in making calls for, e.g., relational classrooms; pedagogies founded on an understanding that stress blocks learning; integration of relational and learning targets; metrics that measure stress producing pedagogies, institutions or tests; and even an end to high stakes testing. Such moves may fly in the face of the relentless policy trajectories of the last 30 years. Perhaps it is time to get over our 'clichés' and 'conventional codes' and collaborate with those in new biosciences that share our concerns.

\section{Acknowledgement}

We would like to express our gratitude for their participation and openness to the people who participated in the IUE and GAESTA research projects. Thanks also to academic colleagues in analytic chemistry - Jim Reynolds and Matthew Turner, University of Loughborough - and neuroscience Andrew Bagshaw, Stephane de Brito and Kimron Shapiro, University of Birmingham. Thanks also to the insightful comments from the reviewers this paper. 


\section{Notes}

1 The body social: synthesising sociology and biology to reconceptualise student identity, British Academy Mid-Career Fellowship (award no: MD140037).

${ }^{2}$ Getting an Early Start to aspirations: Understanding how to promote educational futures in early childhood (GAESTA, Australian Research Council, FT130101332) and Imagining University Education: The perspectives of young people impacted by low socio-economic status and disengagement from school (IUE)(Australian Research Council, DP140103690) were conducted in Australia and have Human Research Ethics Committee Approval from the University of Wollongong.

${ }^{3}$ Pseudonyms are used for names of people and places. See Harwood et al., 2017, for details of the IUE research.

${ }^{4}$ Setting aside for now concerns over animal experimentation itself, findings drawn from model animal studies do present challenges for translation to humans. Neither the experimental conditions (neglect, electric shock) nor the data collection method (death and brain dissection) can be reproduced; the complexity of human social forms and environmental conditions and contexts cannot be accounted for; and the possibility that the tissue-specific cells of human organisms may respond quite differently to those of model animals cannot be discounted. Despite the distance between rodent and human, some leading researchers suggest that the conditions created in animal models are good analogue for poverty or neglect in humans (van Ijzendoorn et al., 2011).

\section{References}

Allen, G. (2011). Early intervention: The next steps. London: HM Government.

Apple, M. (2006). Educating the 'right' way: Markets, standards, God, and inequality, Second Edition. London: RoutledgeFalmer.

Arendt, H. (1981). The life of the mind, one/thinking, two/willing (One volume edition). New York: Harcourt.

Australian Curriculum and Reporting Authority (ACARA). (2017). National assessment program. Accessed 7 February 2017 from https://www.nap.edu.au/about

Atkinson, E., \& DePalma, R. (2009). Un- believing the matrix: Queering consensual heteronormativity. Gender and Education, 21(1), 17-29.

Baker, B. (2015). From ‘somatic scandals' to ‘a constant potential for violence’? The culture of dissection, brain-based learning, and the rewriting/rewiring of 'the child'. Journal of Curriculum and Pedagogy, 12(2), 168-197. doi: 10.1080/15505170.2015.1055394

Bakermans-Kranenburg, M. J., \& van Ijzendoorn, M. H. (2013). Sniffing around oxytocin: Review and meta-analyses of trials in healthy and clinical groups with implications for pharmacotherapy. Translational Psychiatry, 3. doi: 10.1038/tp.2013.34

Barad, K. M. (2007). Meeting the universe halfway. Durham \& London Duke University Press.

Belsky, J., \& van Ijzendoorn, M. H. (2015 Not cited in text). What works for whom? Genetic moderation of intervention efficacy. Review. Development and Psychopathology, 27(1), 1-6. doi: 10.1017/s0954579414001254.

Bevins, R. A., \& Besheer, J. (2006). Object recognition in rats and mice: A one-trial non-matching-tosample learning task to study 'recognition memory'. Nat Protocols, 1(3), 1306-1311. doi: 10.1038/nprot.2006.205

Bibby, T. (2011). Education - An 'impossible profession'? Psychoanalytic explorations of learning and classrooms. London: Routledge.

Bibby, T. (2017). The creative self: Psychoanalysis, teaching and learning in the classroom. London: 
Routledge.

Bomber, L. M., \& Hughes, D. A. (2013). Settling to learn: Settling troubled pupils to learn - why relationships matter in school. London: Worth Publishers.

Booher-Jennings, J. (2005). Below the bubble: ‘educational triage’ and the Texas Accountability System. American Educational Research Journal, 42(2), 231-268.

Brown, J. R. (1991). The laboratory of the mind: Thought experiments in the natural sciences. London: Routledge.

Cacioppo, J. T., Cacioppo, D., \& Cole, S. W. (2013). Social neuroscience and social genomics: The emergence of multi-level integrative analyses. International Journal of Psychological Research, 6(Special Issue): 1-6.

Champagne, F. A. (2009). Epigenetic mechanisms and the transgenerational effects of maternal care. Neuroendorinol, 29(3), 386-397.

Cole, S. W. (2014). Human social genomics. PLOS Genetics, 10(8): e1004601. doi: 10.1371/journal.pgen.1004601

Collingwood, S. (2017). The primary assessment system is an endless anxiety merry-go-round, driven by an engine of mistrust. Times Education Supplement, 2 July 2017. Retrieved from https://www.tes.com/news/school-news/breaking-views/primary-assessment-system-endlessanxiety-merry-go-round-driven

Cummings, E. M., Greene, A. L., \& Karraker, K. H. (2014). Life-span developmental psychology: Perspectives on stress and coping. Hillsdale, N.J. Psychology Press.

Dedovic, K., Renwick, R., Mahani, N. K., Engert, V., Lupien, S. J., \& Pruessner, J. C. (2005) The Montreal Imaging Stress Task: Using functional imaging to investgating the effects of perceiving and processing psychosocial stress in the human brain. Journal of Psychiatry and Neuroscience, 30(5), 315-325.

Deleuze, G., \& Guattari, F. (2008). A thousand plateaus. London: Continuum.

Dukes, C. (1887). Health at school considered in its mental, moral and physical aspects. London: Cassell \& Company Ltd.

Edwards, R., Gillies, V., \& Horsley, N. (2015). Brain science and early years policy: Hopeful ethos or ‘cruel optimism'? Critical Social Policy, 35(2), 167-187.

Fischer, K. W., Goswami, U., \& Geake, J. (2010). The Future of Educational Neuroscience. Mind, Brain, and Education, 4(2), 68-80.

Foucault, M. (1983). The subject and power. In H. L. Dreyfus, \& P. Rabinow (Eds.), Michel Foucault: Beyond structuralism and hermeneutics (pp. 208-226). University of Chicago: University of Chicago Press.

Frost, S. (2016). Biocultural creatures: Towards a new theory of the human. Durham, NC: Duke University Press.

Gillborn, D. (2008). Racism and education: Coincidence or conspiracy? London: Routledge.

Gillborn, D., \& Youdell, D. (2000). Rationing education: Policy, practice, reform and equity. Buckingham: Open University Press.

Gillies, V. (2008). Childrearing, class and the new politics of parenting. Compass, 2(3), 1079-1095.

Groeneveld, M. G., Vermeer, H. J., Linting, M., Noppe, G., van Rossum, E. F. C., \& van Ijzendoorn, M. H. (2013). Children's hair cortisol as a biomarker of stress at school entry. Review of Stress: The International Journal on the Biology of Stress, 16(6), 711-715. doi: 10.3109/10253890.2013.817553.

Gudsnuk, K., \& Champagne, F. A. (2012). Epigenetic influence of stress and the social environment. Ilar Journal, 53(3-4), 279-288. doi: 10.1093/ilar.53.3-4.279.

Gulson, K. N., \& Webb, T. P. (2016). Emerging biological rationalities for policy: (Molecular) 
biopolitics and the new authorities in education. In S. Parker, K. N. Gulson, \& T. Gale (Eds.), Policy and inequality in education (pp. 23-39). Dordrecht: Springer.

Harwood, V. (2006). Diagnosing 'disorderly' children: A critique of behaviour disorder discourses. Oxford: Routledge.

Harwood, V. (2010). Mobile asylums: Psychopathologisation as a personal portable psychiatric prison. Discourse: Studies in the Cultural Politics of Education, 31(4), 437-451.

Harwood, V., \& Allan, J. (2014). Psychopathology at school: Theorising mental disorder in education. Oxford: Routledge.

Harwood, V., \& McMahon, S. (in press). Amidst the reign of behaviour and disorder: Recalling schools as problems. Journal of Historical Sociology.

Harwood, V., Hickey-Moody, A., McMahon, S., \& O’Shea, S. (2017). The politics of widening participation: Making educational futures. Oxford: Routledge.

Heaney, L. M., Ruskiewicz, D. M., Arthur, K. L., Hadjithekli, A., Lindley Aldcroft, M. R., Thomas, C. L. P., Turner, M. A., \& Reynolds, J. C. (2016). Real-time monitoring of exhaled volatiles using atmospheric pressure chemical ionization on a compact mass spectrometer. Bioanalysis, 8(13), 1325-1336.

Hickey-Moody, A. (2009). Unimaginable Bodies: intellectual disablity, performance and becomings. Rotterdam: Sense.

Hickey-Moody, A. (2013). Youth arts and education: Reassembling subjectivity through affect. New York: Routledge.

Hickey-Moody, A. (2014). Affect as method: Feelings, aesthetics, and affective pedagogy. In R. Coleman, \& J. Ringrose (Eds.), Deleuze and Research Methodologies (pp. 79-95). Edinburgh: EUP.

Howard-Jones, P. A. (2014). Neuroscience and education: Myths and messages. Nature Reviews Neuroscience, 15, 817-824. doi: 10.1038/nrn3817.

Hughes, D. A., \& Baylin, J. (2012). Brain-based parenting: The neuroscience of caregiving for healthy attachment. London: W. W. Norton \& Co.

Kenney, M., \& Müller, R. (2016). Of rats and women: Narratives of motherhood in environmental epigenetics. BioSocieties, 12 (1)1-24. doi: 10.1057/s41292-016-0002-7.

Kenway, J., \& Youdell, D. (2011). Emotional geographies of education: Beginning a conversation. Emotion, Space and Society, 4(3), 131-136.

Kraftl, P. (2013). Beyond 'voice', beyond 'agency', beyond 'politics'? Hybrid childhoods and some critical reflections on children's emotional geographies. Emotion, Space and Society, 9(1), 13-23. doi: http://dx.doi.org/10.1016/j.emospa.2013.01.004

Leger, M., Quiedeville, A., Bouet, V., Haelewyn, B., Boulouard, M., Schumann-Bard, P., \& Freret, T. (2013). Object recognition test in mice. Nat. Protocols, 8(12), 2531-2537. doi: 10.1038/nprot.2013.155.

Levy, F. (2017). How to help your teenager cope with stress. Retrieved from http://www.felicialevy.com/2017/03/22/how-to-help-your-teenager-cope-with-anxiety/

Lingard, B., Sellar, S., \& Savage, G. (2014). Re-articulating social justice as equity in schooling policy: The effects of testing and data infrastructures. British Journal of Sociology of Education, 35(5), 710-730.

Malabou, C. (2009). Changing difference. Cambridge: Polity.

Meloni, M. (2014). The social brain meets the reactive genome: Neuroscience, epigenetics and the new social biology. Frontiers in Human Neuroscience, 8(309), 1-12. doi: 10.3389/fnhum.2014.00309

Meloni, M. (2016). Political biology: Science and social value in human heredity from eugenics to 
epigenetics. Basingstoke: Palgrave Macmillan.

Meloni, M., Williams, S., \& Martin, P. (2016). The biosocial: Sociological themes and issues. The Sociological Review Monographs, 64(1), 7-25. doi: 10.1111/2059-7932.12010

Molfese, D. L. (2011). Advancing neuroscience through epigenetics: Molecular mechanisms of learning and memory. Developmental neuropsychology, 36(7), 810-827. doi: 10.1080/87565641.2011.606395.

Munt, V. (2004). The awful truth: A microhistory of teacher stress at Westwood High. British Journal of Sociology of Education, 25(5), 577-591.

Muscatell, K. A., Dedovik, K., Slavich, G. M., Jarcho, M. R., Breen, E. C., \& Bower, J. (2016). Neural mechanisms linking social status and inflammatory response. Social Cognition and Affective Neuroscience, 11(6), 915-922. doi: 10.1093/scan/nsw025.

Noble, K. G., Houston, M., Brito, N. H., Bartsch, H., Kan, E., Kuperman, J. M., Akshoomoff, N. (2015). Family income, parental education and brain structure in children and adolescents. Review of Nat Neuroscience, 18(5), 773-778. doi: 10.1038/nn.3983, http://www.nature.com/neuro/journal/v18/n5/abs/nn.3983.html\#supplementary-information.

Perez, M. (2015). Obtaining Academic Success: Nurturing Grit in Students. Journal of Interpersonal Relations, Intergroup Relations and Identity, 8(Hiver/Winter), 56-63.

Plak, R.D., Merkelbach, I., Kegel, C.A.T., Van IJzendoorn, M.H., \& Bus, A.G. (2016). Brief computer interventions enhance emergent academic skills in susceptible children: A Gene-by-Environment Experiment. Learning and Instruction, 45, 1-8.

Reynolds, J. C., Turner, M. A., Carr, P., Lindley, M. R., \& Creaser, C. (forthcoming). Direct analysis of volatile organic compounds in foods using compact mass spectrometry. Rapid communications in mass spectrometry.

Roberts, C. (2015) Puberty in crisis: The sociology of early sexual development. Cambridge: Cambridge University press.

Romens, S. E., McDonald, J. S., \& Pollak, S. D. (2015). Associations between early life stress and gene methylation in children. Child Development, 86(1), 303-309. doi: 10.1111/cdev.122270.

Saltmarsh, S., \& Youdell, D. (2004). 'Special sport' for misfits and losers: Educational triage and the constitution of schooled subjectivities. International Journal of Inclusive Education, 8(4), 353371.

Sellar, S., \& Lingard, B. (2014). The OECD and the expansion of PISA: New global modes of governance in education. British Educational Research Journal, 40(6), 917-936. doi: 10.1002/berj.3120.

Shaffer, D. R., \& Kipp, K. (2013). Developmental psychology: Childhood and adolescence. Belmont, CA. Cengage Learning.

Slee, R. (2011). The irregular school. London: Routledge.

Teague, L. (2014). 'Acceptance of the limits of knowability in oneself and others': Performative politics and relational ethics in the primary school. Discourse: Studies in the Cultural Politics of Education, 36(3), 398-408. ISSN 0159-6306.

Thompson, G. (2016). Computer adaptive testing, big data and algorithmic approaches to education. British Journal of Sociology of Education. doi: 10.1080/01425692.2016.1158640

Turner, M. A., Bandelow, S., Edwards, L., Patel P., Martin H. J., Wilson, I. D., \& Thomas C. L. (2013). The effect of a paced auditory serial addition test (PASAT) intervention on the profile of volatile organic compounds in human breath: A pilot study. Journal of Breath Research, Mar;7(1):017102. doi: 10.1088/1752-7155/7/1/017102. Epub 2013 Feb 27

van Ijzendoorn, M. H., Bakermans-Kranenburg, M. J., \& Ebstein, R. P. (2011). Methylation matters in 
child development: Toward developmental behavioral epigenetics. Review of Child Development Perspectives, 5(4), 305-310. doi: 10.1111/j.1750-8606.2011.00202.x.

Wastell, D., \& White, S. (2012). Blinded by neuroscience: Social policy, the family and the infant brain. Families, Relationships and Societies, 1(3), 397-414.

Weaver, I. C. G., Hellstron, I. C., Brown, S. E., Andrews, S. D., Dymov, S., Diorio, J., Yhang, T.-Y., Szyf, M., \& Meaney, M. J. (2014). The methyladed-DNA binding protein MBD2 enhances NGF!A (erg-1)-mediated transcriptional activiation of the glucocorticoid receptor. Philosophical Transactions of the Royal Society, B, 369. doi: 20130513.

Williams, J., Stonner, C., Wicker, J., Krauter, N., Derstroff, B., Bourtsoukidis, E., Klupfel, T., \& Kramer, S. (2016). Cinema audiences reproducibly vary the chemical composition of air during films, by broadcasting scene specific emissions on breath (Review). Scientific Reports, 6: Article number: 25464. doi: 10.1038/srep25464.

Willis, J. (2014). The Neuroscience Behind Stress and Learning. Retrieved from https://www.edutopia.org/blog/neuroscience-behind-stress-and-learning-judy-willis

Wilson, E. (2015). Gut feminism. NY: Duke.

Winnicott, D. W. (1971, 2008). Playing and reality. Routledge. Tavistock Publications: London.

Youdell, D. (2006). Impossible bodies, impossible selves: Exclusions and student subjectivities. Dordrecht: Springer.

Youdell, D. (2010). Pedagogies of becoming in an end-of-the-line 'special' school. Critical Studies in Education, 51(3), 313-324.

Youdell, D. (2011). School trouble: Identity, power and politics in education. London: Routledge.

Youdell, D. (2014). From policy sociology to assemblage ethnography. In K. Gulson, A. Metcalfe, \& M. Clarke (Eds.), Post-Structural Theory and Education Policy. London: Routledge.

Youdell, D. (2017). Bioscience and the sociology of education: The case for biosocial education. British Journal of Sociology of Education, 1-14. doi: 10.1080/01425692.2016.1272406.

Youdell, D., \& Armstrong, F. (2011). A politics beyond subjects: The affective choreographies and smooth spaces of schooling. Emotion, Space, Society, 4(1), 144-150.

Youdell, D., \& Lindley, M. R. (forthcoming). Biosocial education. London: Routledge.

Zembylas, M. (2007). Five pedagogies, a thousand possibilities: Struggles for hope and transformation in education. Rotterdam: Sense. 


\section{Languages of Stress Figures}

Figure 1. fMRI imaging of brain activity during MiST test.

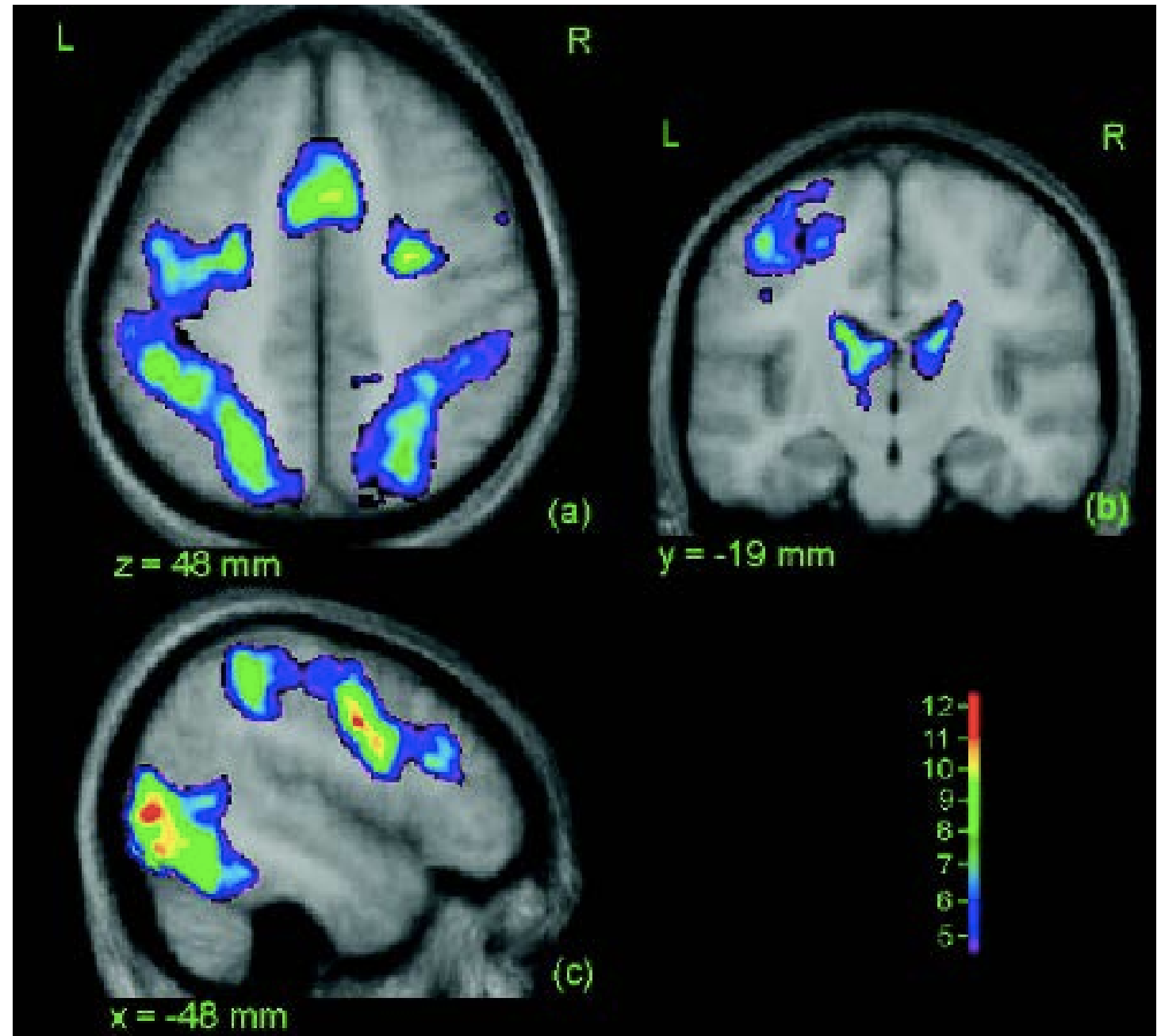

Statistical parametric map displaying significant activations with blood oxygenation level-dependent (BOLD) signal as a result of performing the MIST in study $3(n=22)$. Areas significantly activated as a result of performing the MIST include the visual association cortex, the sensory and motor cortices, the angular gyrus, the thalamus and the cingulate gyrus, as shown here in (a) horizontal, (b) coronal and (c) sagittal slices. All areas shown exceed the threshold for statistical significance of $t>4.5$. Source: Dedovic et al 2005. 
Insert Figure 2. Volatile Organic Compounds in Exhaled Breath during PASAT Test.
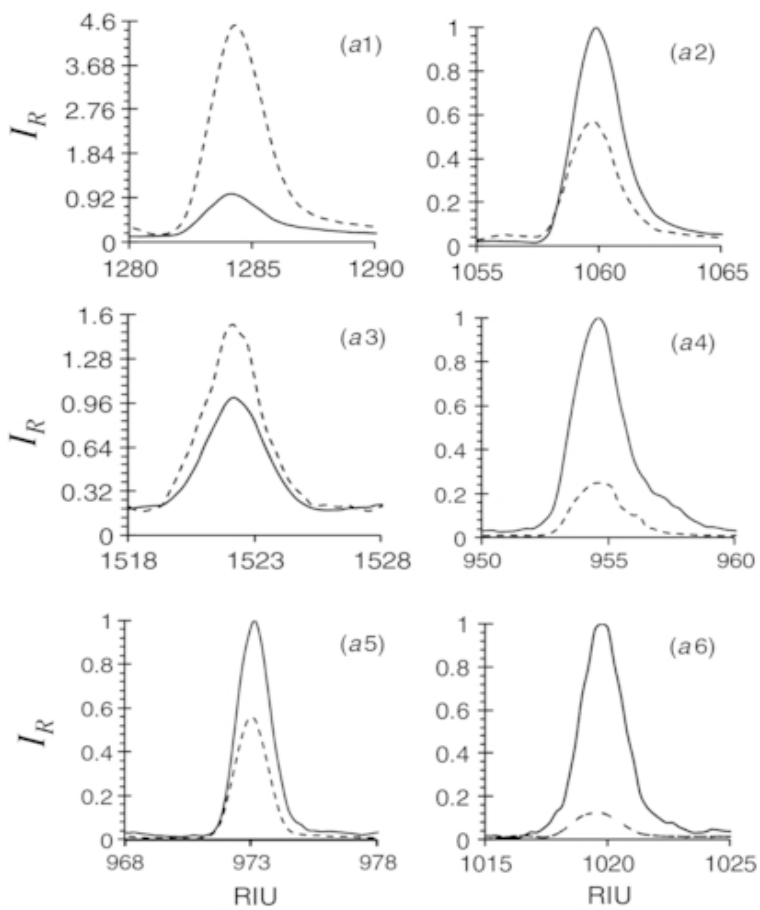

Overlaid extracted ion chromatograms (XIC) responses for stressed experimental session (dashed line) and neutral experimental session (solid line) for stress sensitive breath components: indole ( $\alpha 1), 2$ hydroxy-1-phenylethanone ( $\alpha 2)$, 2-methylpentadecane ( $\alpha 3)$, unknown terpene ( $\alpha 4)$, benzaldehyde( $\alpha 5$ ) and 2-ethylhexan-1-ol ( $\alpha 6)$ from a single male participant. Theintensities (IR) displayed have been normalized with respect to theneutral experimental session to indicate those components that have been up-regulated and down-regulated as a result of undertaking the PASAT. Source: Turner et al 2013. 
Figure 3. Atmospheric stress in the cinema
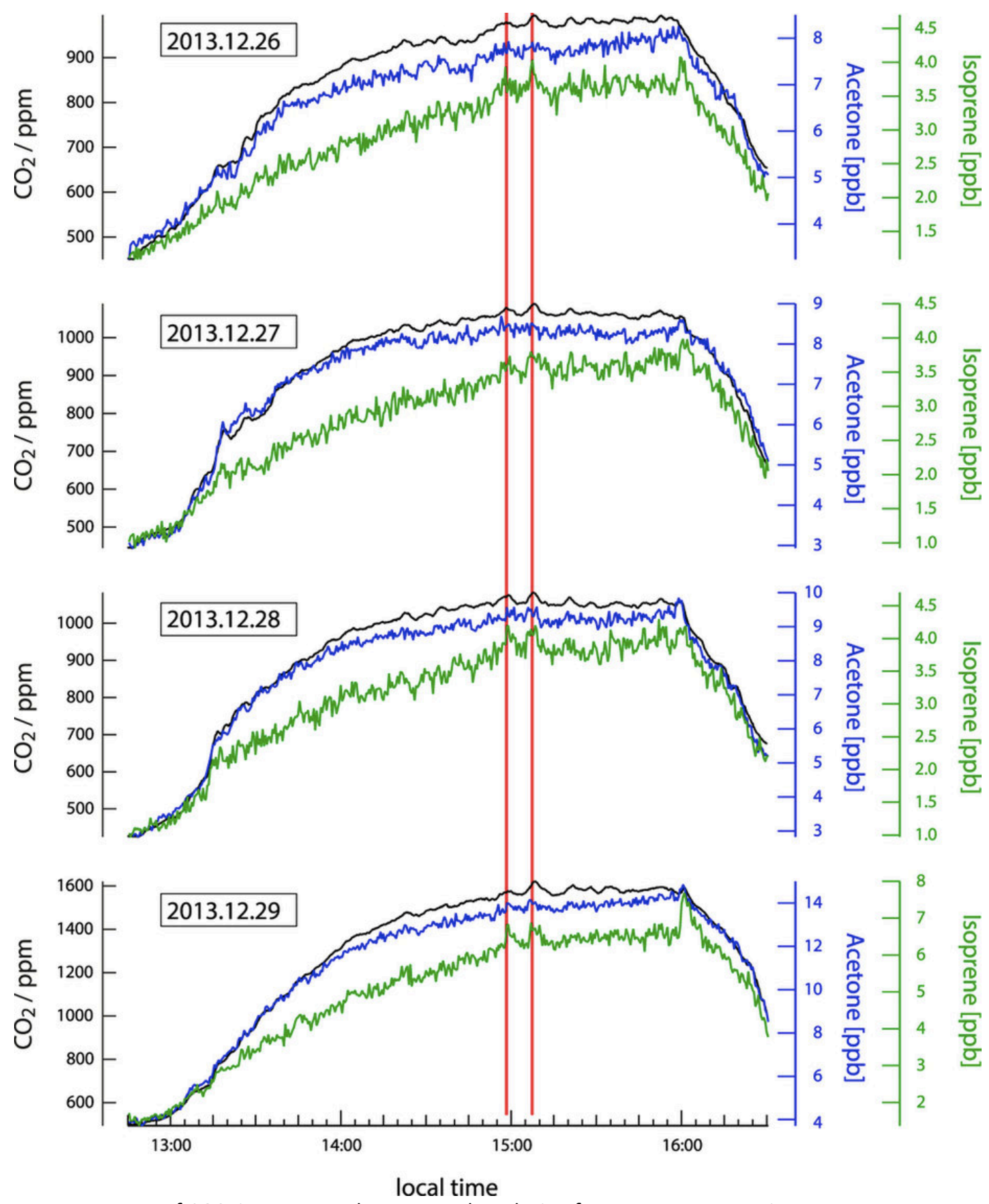

Measurements of $\mathrm{CO} 2$, isoprene and acetone taken during four separate screenings of “Hunger Games 2".Source: Williams et al 2016. 
Figure 4. VOC mass spectrums in cinema auditorium during types of film segment

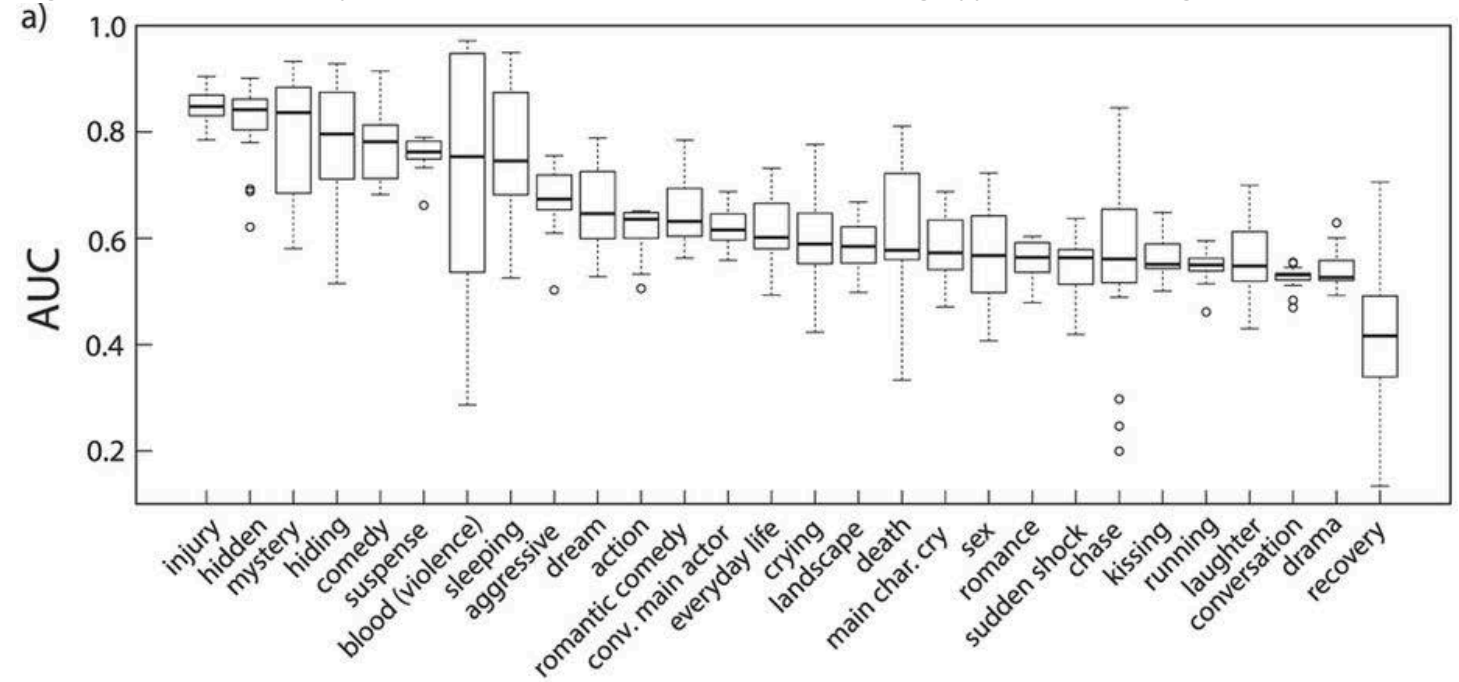

b)

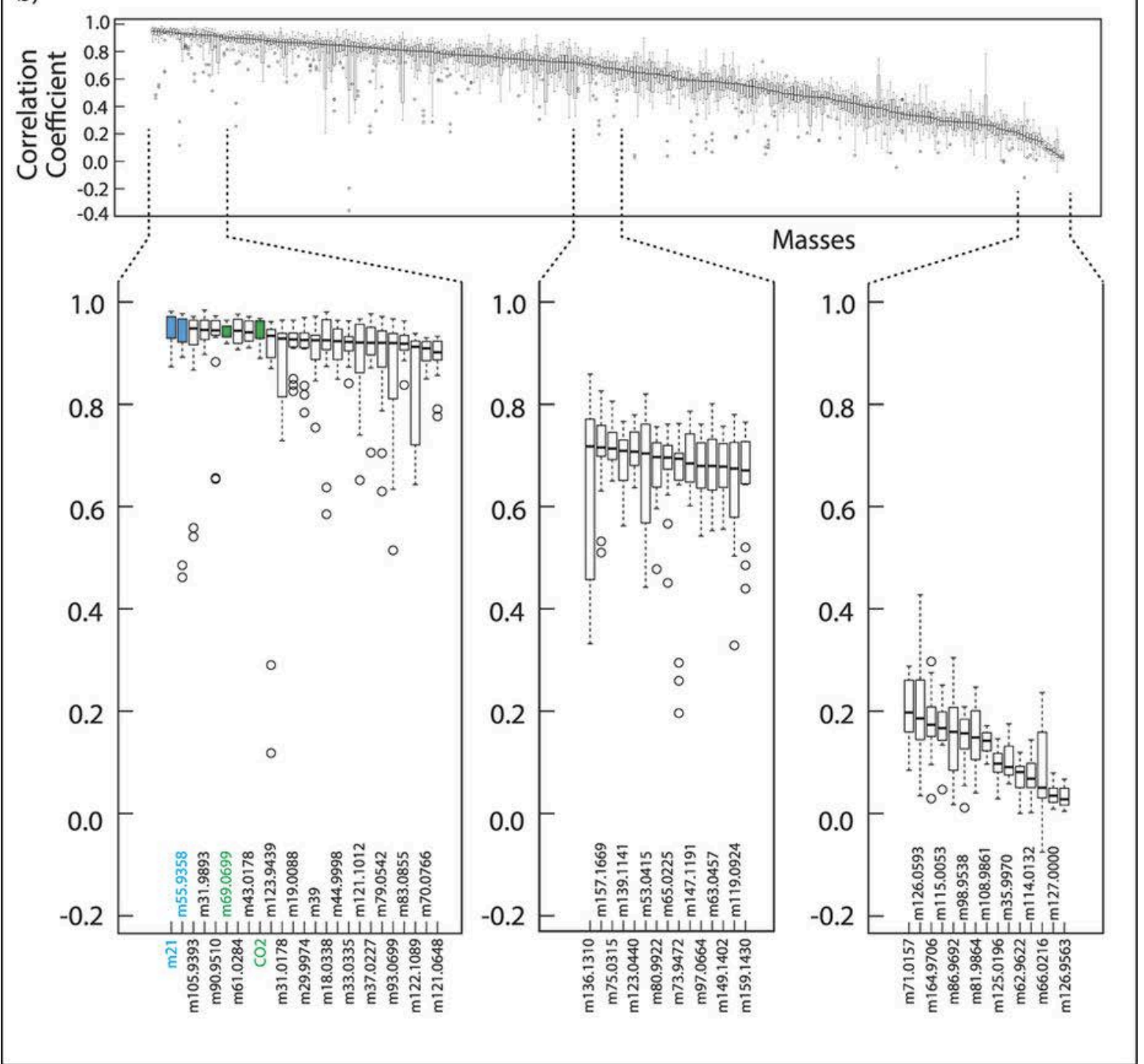

The boxes indicate the extent of $25 \%$ of the data either side of the median (solid line). The dashed vertical line represents the lowest/highest datapoints that are still in the 1.5 interquartile range while the circles are outliers. (a) shows AUC which expresses the ratio between true positives (when the model correctly predicted labels based on mass decision trees) and false positives (backward prediction). A random prediction produces an AUC value of 0.5 . (b) shows the ability of an individual mass to be predicted by the labels (forward prediction). The performance of this prediction versus the 
real value for VOC mixing ratios is given as the Pearson's correlation coefficient ( $r$ ). High correlation coefficients indicate the predictive model was successful for that particular species, and not that all species with high correlation coefficients are inter-correlated. Source: Williams et al 2016. 